\title{
Genetic Variants and Mixed Sport Disciplines: A Comparison among Soccer, Combat and Motorcycle Athletes
}

\author{
${ }^{1}$ Paolo Cocci, ${ }^{1}$ Laura Pistolesi, ${ }^{1}$ Marco Guercioni, ${ }^{1}$ Luca Belli, ${ }^{2}$ Davide Carli, \\ ${ }^{1}$ Francesco Alessandro Palermo* \\ ${ }^{1}$ School of Biosciences and Veterinary Medicine, University of Camerino, Camerino, Italy. ${ }^{2}$ Athletic Thai \\ Gym, Rimini, Italy.
}

Submitted 09 July 2018; Accepted in final form 01 September 2018.

\begin{abstract}
Background. Soccer, combat sports and motorcycling have all been classified as mixed in terms of their metabolism predominance thus showing a common multifaceted nature of physical requirements, which include aerobic capacity, strength, endurance, power and agility. Objectives. The aim of the current study was to compare allelic and genotype frequencies of four well-known polymorphisms among athletes from different mixed sport disciplines in order to investigate genetic markers suitable for distinguishing the predominant components of these sports. Methods. Genotyping for the angiotensin-converting enzyme (ACE) insertion/deletion (I/D), $\alpha$-actinin-3 (ACTN3) R577X, muscle-specific creatine kinase (CK-MM) A/G and peroxisome proliferator-activated receptor alpha (PPAR $\alpha$ ) G/C polymorphisms among 113 professional athletes from motorcycling, soccer and combat sports was performed by PCRRFLP method. Results. We found that the G allele of the PPAR $\alpha$ polymorphism was significantly $(p<0.05)$ more frequent in soccer players than in combat sport athletes or motorcycle riders. In addition, we observed that the genotype frequency of AA of CK-MM (rs8111989) polymorphism in soccer players was significantly $(\mathrm{p}<0.05)$ higher than combat athletes. On the contrary, both ACE I/D and ACTN3 R577X polymorphisms do not enable to distinguish between these disciplines. Conclusions. Our findings indicate that the PPAR $\alpha$ polymorphism may be suitable as potential distinguish genetic marker among mixed sport disciplines.
\end{abstract}

KEY WORDS: Athletic Performance, Sport Genetics, ACE, ACTN3, PPARa.

\section{INTRODUCTION}

A greater part of sport games nowadays can be defined as "mixed energy system" disciplines (1) in which the effort is of intermittent characteristics with the involvement of both aerobic and anaerobic metabolic pathways (2). In this regard, physical fitness is one of the most important elements that affect the performance of mixed sport athletes because of the high physical demand due to the intermittent activity (3). Indeed, power and endurance can be considered the key fitness elements for mixed sport disciplines such as soccer, wrestling and motorcycling (4-6). All these sports have been classified as mixed in terms of their metabolism predominance thus showing a common multifaceted nature of physical requirements which include aerobic capacity, strength, endurance, power and agility (4-6). Nevertheless, descriptive studies show that athlete-specific physiological characteristics may differ widely across these disciplines suggesting the presence of different sport-related profiles in terms of ratio

*. Corresponding Author:

Francesco Alessandro Palermo, Associate Professor

School of Biosciences and Veterinary Medicine, University of Camerino, Via Gentile III Da Varano, I-62032 Camerino (MC), Italy.

E-mail: francesco.palermo@unicam.it 
between endurance and speed. Athletes of mixed sport disciplines are not clearly "endurance" or "power" oriented, thus showing a wide phenotypic heterogeneity (7). It is well established that sprint/power and endurance capacities are influenced by genetics (8) but few studies have examined the link between genetic factors and athletic performance in mixed athletes. Among the candidate polymorphisms potentially associated with muscle function and physical performance, the most extensively studied are the angiotensin-converting enzyme (ACE), the R577X variant of the actinin- $\alpha 3$ gene (ACTN3), the muscle isoform of creatine kinase (CK-MM), the peroxisome proliferator-activated receptor $\alpha(\mathrm{PPAR} \alpha)$ and recently the SLC2A4 (914). The alternative polymorphic variants of these candidate polymorphisms were demonstrated to be associated with sprint/power or endurancerelated disciplines with reasonable replication in different groups of athletes (15-18). Indeed, the Iallele of the insertion(I)/deletion(D) polymorphism in the ACE gene is one of the most suggested determinant of aerobic capacity in endurance-oriented performance (8). Similarly, the PPARa G, the ACTN3 X and the CK-MM A alleles are all involved in contributing to improved aerobic performance $(16,17,19)$. On the other hand, the ACE D, the PPARa C, the ACTN3 $R$ and the CK-MM $G$ alleles are speculated to be more associated with strengthoriented performance $(8,16,20)$. Given that the contribution of specific genes to sports performance has been investigated mostly in athletes who are at the two end-points of the human sports performance continuum, lesser is known about the application of sport genomics to more complex disciplines which don't show specific phenotypes. Therefore, the aim of the current study was to compare allelic and genotype frequencies of four well-known polymorphisms among athletes from different mixed sport disciplines in order to investigate genetic markers suitable for distinguishing the predominant components of these sports.

\section{MATERIALS AND METHODS}

Participants. A total of 113 Italian male elite athletes from three different sports at professional and national level were invited to participate in the study. Athletes were classified as elite due to their full time participation in sport and they regularly competed at international or national level (21). The sample included 37 combat sport athletes (mean age $25.96 \pm 9.29$ years), 21 motorcycle riders (mean age $22.58 \pm 7.48$ years) and 55 soccer players $(24.56 \pm 8.71$ years $)$. The athletes were all Caucasian to avoid potential problems of population stratification, as reported by the "Strengthening the Reporting of Genetic Association Studies" (STREGA) statement. The study was performed in accordance with the required ethical standards. Written informed consent to participate in the study was obtained from the entire interested subject or from a parent (in the case of minors) according to current Italian law. The study complied with the guidelines stated in the Helsinki Declaration.

Collection of samples and extraction of DNA from buccal cells. The buccal cells donated by the participants were collected using cotton swabs (Fisher Scientific). The subjects abstained from smoking, drinking, and eating for 2 hours before buccal swab collection. DNA was extracted from the buccal cells after period of storage at $4^{\circ} \mathrm{C}$, using a protocol from Saab et al. (22). Then the tubes were heated at $95{ }^{\circ} \mathrm{C}$ for 7 min, after which the swab was carefully removed, discarded and treated with $30 \mu \mathrm{L}$ of Tris- $\mathrm{HCl}(1$ $\mathrm{M} ; \mathrm{pH}$ 8.0). After centrifugation for $2 \mathrm{~min}$ at $13,000 \mathrm{rpm}$, the resulting supernatant (DNA) was assessed for both purity and integrity by using spectrometric and electrophoretic methods respectively.

Determination of ACE, ACTN3, PPARa, and CK-MM, genotypes. Genotyping of the ACE (rs4646994) and ACTN3 (rs 1815739) polymorphisms were assessed by polymerase chain reaction (PCR) using primers previously described $(23,24)$. Amplification of ACE was performed in a final volume of $25 \mu$ l containing $2 \mu \mathrm{l}$ genomic DNA template, $12.5 \mu \mathrm{l}$ of $2 \mathrm{X}$ PCR Master Mix (Fermentas, ThermoFisher Scientific), $1 \mu$ l of each primer $(10 \mu \mathrm{M}$; Eurofins MWG Operon) and $8.5 \mu 1$ DEPC-treated water. Thermo-cycling for ACE reaction was for $5 \mathrm{~min}$ at $95{ }^{\circ} \mathrm{C}$, followed by 35 cycles of $30 \mathrm{~s}$ at $94{ }^{\circ} \mathrm{C}$, $45 \mathrm{~s}$ at $58^{\circ} \mathrm{C}$ and $45 \mathrm{~s}$ at $72{ }^{\circ} \mathrm{C}$. Amplification of ACTN3 was carried out in a final volume of 25 $\mu 1$ containing $2 \mu \mathrm{l}$ DNA template, $12.5 \mu \mathrm{l}$ of $2 \mathrm{X}$ PCR Master Mix (Fermentas, ThermoFisher Scientific), $5.5 \mu \mathrm{L}$ DEPC-treated water and $5 \mu \mathrm{L}$ of a mixture of four primers at different concentration, as reported by Schadock et al. (2015) (24). ACTN3 gene PCR amplification was performed as follows: $95{ }^{\circ} \mathrm{C}$ for $5 \mathrm{~min}$, 
followed by 35 cycles at $95{ }^{\circ} \mathrm{C}$ for $20 \mathrm{sec}, 67{ }^{\circ} \mathrm{C}$ for $20 \mathrm{sec}$ and at $72{ }^{\circ} \mathrm{C}$ for $45 \mathrm{sec}$, followed by a final step at $72{ }^{\circ} \mathrm{C}$ for $3 \mathrm{~min}$. All DNA amplicons were electrophoresed through a $2 \%$ agarose gel and visualized under a UV light transilluminator by staining with SafeView $^{\mathrm{TM}}$ Classic dye (Abm®). The PPAR $\alpha$ (rs4253778) and CK-MM (rs8111989) polymorphisms were assessed by Restriction Fragment Length Polymorphism (RFLP) analysis $(16,25)$. Briefly amplifications of PPAR $\alpha$ and CK-MM were conducted in a final volume of $25 \mu \mathrm{l}$ containing $2 \mu \mathrm{l}$ genomic DNA template, $12.5 \mu \mathrm{l}$ of $2 \mathrm{X}$ PCR Master Mix (Fermentas), $1 \mu \mathrm{l}$ of each primer $(10 \mu \mathrm{M}$; Eurofins MWG Operon) and 8.5 $\mu 1$ DEPCtreated water. For PPAR $\alpha$ and CK-MM gene PCR amplifications, the standard program was used as follows: one initial denaturation step at $95{ }^{\circ} \mathrm{C}$ for $3 \mathrm{~min}$, followed by 38 cycles of $30 \mathrm{sec}$ at $94{ }^{\circ} \mathrm{C}, 40 \mathrm{sec}$ of annealing at $57^{\circ} \mathrm{C}$, and $40 \mathrm{sec}$ of extension at $72{ }^{\circ} \mathrm{C}$, followed by a final elongation cycle at $72{ }^{\circ} \mathrm{C}$ for $3 \mathrm{~min}$. Samples were then digested at $65{ }^{\circ} \mathrm{C}$ for $2 \mathrm{~h}$ with the appropriate restriction enzyme (1 U TaqI; ThermoFisher Scientific) and with $1 \times$ Restriction Enzyme Buffer (ThermoFisher Scientific) in a volume of $20 \mu \mathrm{L}$. The digested samples were then analyzed on $2 \%$ agarose gels after SafeView ${ }^{\mathrm{TM}}$ Classic dye (Abm®) staining. CK-MM amplicons were treated with the restriction endonuclease NcoI (Thermo Fisher Scientific) at $37{ }^{\circ} \mathrm{C}$ for $2 \mathrm{~h}$. The restriction fragment lengths of the products were analyzed in $1.5 \%$ agarose gel followed by staining with SafeView ${ }^{\text {TM }}$ Classic dye (Abm $\left.{ }^{\circledR}\right)$.

Statistical analysis. A chi-square $\left(\mathrm{X}^{2}\right)$ test was used to assess the fit of the observed genotype frequencies to the Hardy-Weinberg equilibrium (HWE) and to compare alleles and genotype frequencies between athletes from different sports. Total genotype score (TGS) was calculated from the selected polymorphisms following the procedure previously described (26) and was used for calculating the probability of possessing optimal genetic profile for endurance. The distribution of TGS was designed in the overall study population and in the athletes of each sport discipline, and differences in TGS were analysed in these groups by one-way analysis of variance (ANOVA) using the GraphPad Prism software.

\section{RESULTS}

In this study, we compared genotype and allele frequencies of four gene variants among combat sport athletes, motorcycle riders and soccer players (Table 1, 2, 3, 4). Genotype distributions met $\mathrm{H}-\mathrm{W}$ equilibrium in all athletic groups. We found significant $(\mathrm{p}=0.0438)$ differences in the PPAR $\alpha$ genotype distribution among all sporting disciplines (Table 1). The frequency of the GG genotype $(p=0.0310)$ and $G$ allele $(p=0.0064)$ was higher in the soccer player group compared with the motorcycle rider group. Likewise, frequency of the GG genotype $(p=0.0462)$ and $\mathrm{G}$ allele $(\mathrm{p}=0.0172)$ was higher in the soccer players compared with the combat sport athletes (Table 1). The odds ratios of being a soccer player if the subject had the GG genotype (dominant model) were 0.2753 (95\% confidence interval: $0.0963-0.7868)$ and 0.3409 (95\% confidence interval: 0.1434-0.8104) compared to the motorcycle riders and combat sport athletes, respectively. We did not find differences between the motorcycle riders and combat sport athletes.

For CK-MM, the AA genotype was found to be at high significant $(p=0.0392)$ frequency in the soccer player group compared to combat athletes (Table 2). There was no statistically significant difference between CK-MM gene polymorphism genotype and allele distributions between motorcycle riders and combat athletes or soccer players (Table 2).

Overall, no statistically significant differences were found among athlete groups with regard to genotype distribution and allele frequencies of both ACE and ACTN3 polymorphisms (Table 3, 4). Mean TGS based on the four polymorphisms in each group is shown in Figure 1. TGS values were very similar among the three groups and there were no statistically significant differences. In the soccer player group, the mean \pm SEM of the TGS was $55.91 \pm 2.57$, with three athletes having the highest scores (i.e. TGS $=87.5$ ), and the kurtosis statistic was (-) $1.788 \pm 1.632$ (SE) (Figure 1). In the combat athlete and motorcycling rider groups, the mean \pm SEM of the TGS was 51.01 \pm 2.76 and $53.57 \pm 3.13$, respectively (kurtosis statistics \pm SE: $-1.701 \pm 1.632$ for combat athletes; $-1.250 \pm 1.632$ for motorcycling riders) (Figure 1). The distribution in soccer players was shifted to towards the right (i.e. higher TGS) compared to both motorcycling riders and combat athletes. 
Table 1. Genotype and allele frequencies of PPAR $\alpha$ polymorphism (rs4253778) in motorcycle riders $(n=21)$, combat sport athletes $(n=37)$ and soccer players $(n=55)$.

\begin{tabular}{|c|c|c|c|c|c|c|c|}
\hline & $\mathrm{Mr}$ & $\mathrm{C}$ & $\mathrm{Sp}$ & $\begin{array}{l}\mathrm{p}\left(\chi^{2}\right) \\
\text { overall }\end{array}$ & $\begin{array}{c}\mathrm{p}\left(\chi^{2}\right), \\
\operatorname{Mr} v s \mathrm{C}\end{array}$ & $\begin{array}{c}\mathrm{p}\left(\chi^{2}\right) \\
\operatorname{Mr} v s \mathrm{Sp}\end{array}$ & $\begin{array}{c}\mathrm{p}\left(\chi^{2}\right), \\
\mathrm{C} v s \mathrm{Sp}\end{array}$ \\
\hline \multicolumn{8}{|l|}{ Genotype } \\
\hline GG & $8(38.1)$ & $16(43.2)$ & $38(69.1)$ & 0.0438 & 0.7472 & 0.0310 & 0.0462 \\
\hline $\mathrm{GC}$ & $10(47.6)$ & 18 (48.6) & $15(27.3)$ & & & & \\
\hline $\mathrm{CC}$ & $3(14.3)$ & $3(8.1)$ & $2(3.6)$ & & & & \\
\hline $\begin{array}{c}\text { HWE-p } \\
\text { value }\end{array}$ & 0.9648 & 0.5034 & 0.7347 & & & & \\
\hline \multicolumn{8}{|l|}{ Allele } \\
\hline$p(\mathrm{G})$ & 0.6190 & 0.6757 & 0.8273 & 0.0105 & 0.5374 & 0.0064 & 0.0172 \\
\hline$q(\mathrm{C})$ & 0.3810 & 0.3243 & 0.1727 & & & & \\
\hline
\end{tabular}

$M r$ : Motorcycle riders. $C$ : Combat athletes. Sp: Soccer players. HWE: Hardy-Weinberg Equilibrium. Values in parentheses are percentages. Bold text indicates a statistically significant difference with a pvalue less than 0.05 .

Table 2. Genotype and allele frequencies of CK-MM polymorphism (rs8111989) in motorcycle riders $(n=21)$, combat sport athletes $(n=37)$ and soccer players $(n=55)$.

\begin{tabular}{|c|c|c|c|c|c|c|c|}
\hline & $\mathrm{Mr}$ & $\mathrm{C}$ & $\mathrm{Sp}$ & $\begin{array}{c}\mathrm{p}\left(\chi^{2}\right), \\
\text { overall }\end{array}$ & $\begin{array}{c}\mathrm{p}\left(\chi^{2}\right), \\
\operatorname{Mr} v s \mathrm{C}\end{array}$ & $\begin{array}{c}\mathrm{p}\left(\chi^{2}\right) \\
\operatorname{Mr} v s \mathrm{Sp}\end{array}$ & $\begin{array}{c}\mathrm{p}\left(\chi^{2}\right) \\
\mathrm{C} v s \mathrm{Sp}\end{array}$ \\
\hline \multicolumn{8}{|l|}{ Genotype } \\
\hline AA & $3(14.3)$ & $5(13.5)$ & $20(36.4)$ & 0.0586 & 0.8982 & 0.0875 & 0.0392 \\
\hline $\mathrm{AG}$ & $14(66.7)$ & $23(62.2)$ & $22(40.0)$ & & & & \\
\hline GG & $4(19.0)$ & $9(24.3)$ & $13(23.6)$ & & & & \\
\hline $\begin{array}{l}\text { HWE- } p \\
\text { value }\end{array}$ & 0.2840 & 0.1166 & 0.1658 & & & & \\
\hline \multicolumn{8}{|l|}{ Allele } \\
\hline$p(\mathrm{G})$ & 0.5238 & 0.5541 & 0.4364 & 0.2629 & 0.7533 & 0.3334 & 0.1173 \\
\hline$q(\mathrm{~A})$ & 0.4762 & 0.4459 & 0.5636 & & & & \\
\hline
\end{tabular}

$M r$ : Motorcycle riders. C: Combat athletes. Sp: Soccer players. HWE: Hardy-Weinberg Equilibrium. Values in parentheses are percentages. Bold text indicates a statistically significant difference with a pvalue less than 0.05 .

\section{DISCUSSION}

The main finding of the present study was that the $\mathrm{G}$ allele of the PPAR $\alpha$ polymorphism is more frequent in soccer players than in combat sport athletes or motorcycle riders. This difference was not found among combat sport athletes compared to motorcycle riders. In their comprehensive meta-analysis, Lopez-Leon et al. have recently showed a higher frequency of the GG genotype and $G$ allele among athletes with high ability in endurance sports (27). Our finding that the PPAR $\alpha$ polymorphism is overrepresented in athletes playing soccer can be supported by the data presented in Ahmetov et al. (2013) (9) and in Maciejewska et al. (2011) (28) which indicated the use of this polymorphism analysis in team sports selection. On the contrary, studies to date demonstrate that the $\mathrm{C}$ allele seems to be associated with hypertrophic effects as suggested by the allele 
over-representation in power-oriented athletes (9). Our results might be explained, at least partly, by the role that PPAR $\alpha$ plays on regulation of metabolism in the skeletal and heart muscles. There is evidence that this receptor is involved in controlling the expression of lipid and glucose target genes and in activating the mitochondrial fatty acid $\beta$ oxidation in endurance-trained athletes (29). It is known that PPAR $\alpha$ expression is higher in slow- twitch fibers (type I) - which are oxidative fibers, predisposed to slower-sustained activities - than in type II fast-twitch muscle fibers (30). This finding highlights the potential involvement of PPAR $\alpha$ in the adaptive metabolic response to endurance training that requires a sustained muscular contraction for a prolonged time (31). In addition, our results indicate that aerobic rather than anaerobic metabolism might be crucial for the game performance in soccer.

Table 3. Genotype and allele frequencies of ACE/ID polymorphism (rs4646994) in motorcycle riders $(n=21)$, combat sport athletes $(n=37)$ and soccer players $(n=55)$.

\begin{tabular}{|c|c|c|c|c|c|c|c|}
\hline & $\mathrm{Mr}$ & $\mathrm{C}$ & $\mathrm{Sp}$ & $\begin{array}{c}\mathrm{p}\left(\chi^{2}\right), \\
\text { overall }\end{array}$ & $\begin{array}{l}\mathrm{p}\left(\chi^{2}\right) \\
\operatorname{Mr} v s \mathrm{C}\end{array}$ & $\begin{array}{c}\mathrm{p}\left(\chi^{2}\right) \\
\mathrm{Mr} v s \mathrm{Sp}\end{array}$ & $\begin{array}{c}\mathrm{p}\left(\chi^{2}\right), \\
\mathrm{C} v s \mathrm{Sp}\end{array}$ \\
\hline \multicolumn{8}{|l|}{ Genotype } \\
\hline II & $5(23.8)$ & $4(10,8)$ & 7 (12.7) & 0.6258 & 0.3319 & 0.3802 & 0.9621 \\
\hline ID & $9(42.9)$ & $22(59,5)$ & $32(58.2)$ & & & & \\
\hline DD & $7(33.3)$ & $11(29,7)$ & $16(29.1)$ & & & & \\
\hline $\begin{array}{l}\text { HWE-p } \\
\text { value }\end{array}$ & 0.5361 & 0.1558 & 0.1467 & & & & \\
\hline \multicolumn{8}{|l|}{ Allele } \\
\hline$p(\mathrm{D})$ & 0.5476 & 0.5946 & 0.5818 & 0.2629 & 0.7533 & 0.3334 & 0.1173 \\
\hline$q(\mathrm{I})$ & 0.4524 & 0.4054 & 0.4182 & & & & \\
\hline
\end{tabular}

Table 4. Genotype and allele frequencies of ACTN3 polymorphism (rs1815739) in motorcycle riders $(n=21)$, combat sport athletes $(n=37)$ and soccer players $(n=55)$.

\begin{tabular}{|c|c|c|c|c|c|c|c|}
\hline & $\mathrm{Mr}$ & $\mathrm{C}$ & $\mathrm{Sp}$ & $\begin{array}{c}\mathrm{p}\left(\chi^{2}\right), \\
\text { overall }\end{array}$ & $\begin{array}{c}\mathrm{p}\left(\chi^{2}\right), \\
\operatorname{Mr} v s \mathrm{C}\end{array}$ & $\begin{array}{c}\mathrm{p}\left(\chi^{2}\right) \\
\mathrm{Mr} v s \mathrm{Sp}\end{array}$ & $\begin{array}{c}\mathrm{p}\left(\chi^{2}\right) \\
\mathrm{C} v s \mathrm{Sp}\end{array}$ \\
\hline \multicolumn{8}{|l|}{ Genotype } \\
\hline $\mathrm{RR}$ & $4(42.9)$ & $8(54.1)$ & $15(58.2)$ & 0.2732 & 0.5364 & 0.0790 & 0.4738 \\
\hline $\mathrm{RX}$ & $9(19.0)$ & $20(21.6)$ & $32(27.3)$ & & & & \\
\hline $\mathrm{XX}$ & $8(38.1)$ & $9(24.3)$ & $8(14.5)$ & & & & \\
\hline $\begin{array}{c}H W E-p \\
\text { value }\end{array}$ & 0.6123 & 0.6184 & 0.1752 & & & & \\
\hline \multicolumn{8}{|l|}{ Allele } \\
\hline$p(\mathrm{R})$ & 0.5952 & 0.5135 & 0.4364 & 0.1938 & 0.3958 & 0.0796 & 0.3037 \\
\hline$q(\mathrm{X})$ & 0.4048 & 0.4865 & 0.5636 & & & & \\
\hline
\end{tabular}

$M r$ : Motorcycle riders. $C$ : Combat athletes. Sp: Soccer players. HWE: Hardy-Weinberg Equilibrium. Values in parentheses are percentages. Bold text indicates a statistically significant difference with a pvalue less than 0.05 .

This observation can be further supported by considering the significantly higher presence of CK-MM AA genotype in soccer than in combat sport athletes found in our work. In this regard, previous studies have demonstrated that $\mathrm{CK}$ MM A allele is over-represented in endurance athletes and is associated with high values of $\mathrm{VO}_{2 \max }$, whereas the CK-MM $\mathrm{G}$ allele is 
associated with power athlete status (16). This latter finding agrees with the more power and strength-oriented characteristics of combat sports (32). In terms of the CKM gene polymorphism, our results are consistent with the notion that a prolonged capacity for muscular effort plays a key role in the determination of success in soccer players. On the other hand, the G allele may be one of the factors beneficial to fight performance, as it predisposes toward developing power and strength qualities which seem to be the most important components of the combat athletes's physiology. Similarly, motorcycle riders exhibit many of the characteristic mixed features of power activities showing great muscle mass and high strength (4), physical attributes required for elite motorcycles which are exposed to $g$-forces of acceleration and braking, heavy vibrating motorcycle engine equipment and must be stay in a seated position for quite long periods.
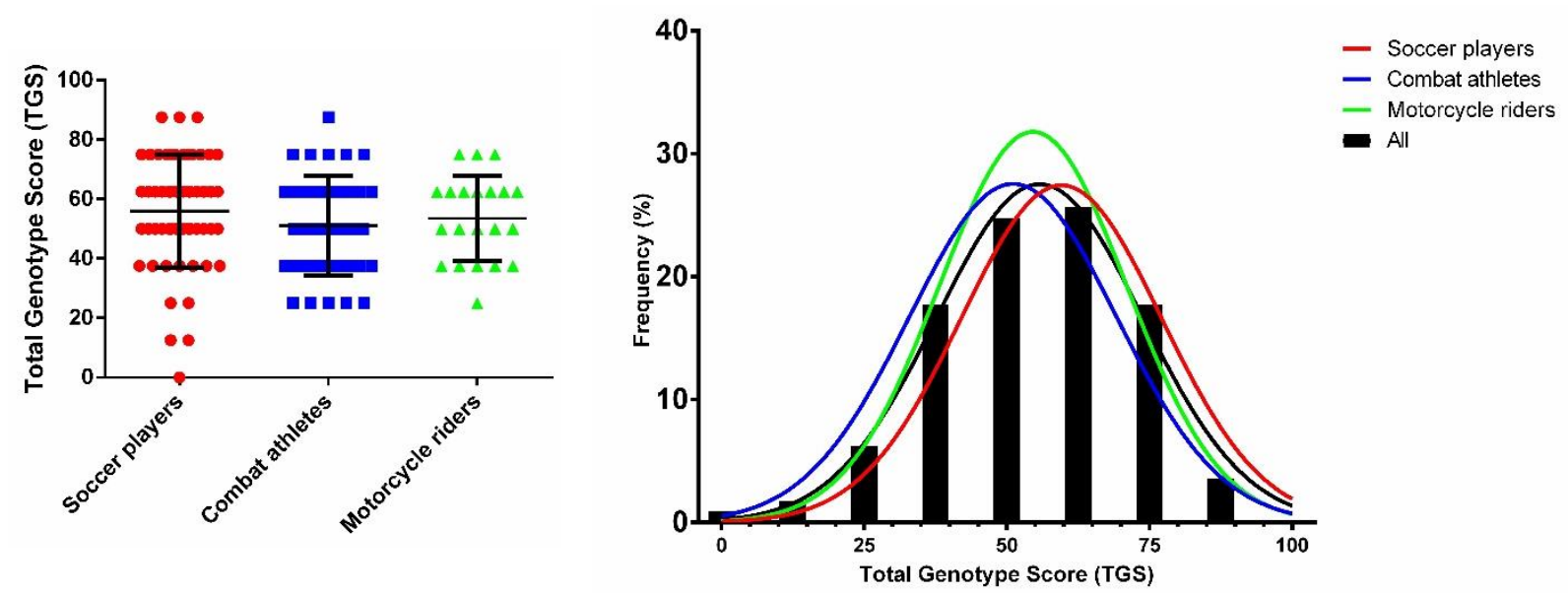

Fig 1. Total Genotype Scores (TGS) and TGS frequency distribution of soccer players, combat sport athletes and motorcycle riders. Data are expressed as mean \pm SD.

Also our results indicate that neither ACE I/D nor ACTN3 R577X polymorphisms are significantly associated with the athlete status in Italian male soccer players, motorcycle riders and combat athletes. Thus, both polymorphisms do not seem to exert a major influence on the athletic performance in sprint/power oriented sports. These findings are in accordance with those by Massidda et al. (2012) (33) who found that ACE DD genotype was not associated with elite athletic status in Italian male athletes and with those by Scott et al. (2010) (34) who showed the weakness of ACE genotype as determinant of elite sprint athletic status.

Other investigations have found that ACTN3 RR genotype is not a determinant of both elite soccer and short-distance running athletic status (33) but is highly associated with elite wrestlers (35). Similarly, the genotype distribution of the ACTN3 gene was found not significantly different among young male athletes representing different sport disciplines (36). On the other hand, some authors have reported a positive association between ACTN3 XX genotype and endurance performance (37) suggesting that the absence of $a$-Atn 3 protein could be a major determinant of endurance sports. We note in this regard that although a broad number of studies demonstrates evidences for a real association between ACE I/D / ACTN3 R577X polymorphisms and athletic status, many works have failed to observe any type of association. Overall, our findings may indicate that both ACE I/D and ACTN3 R577X polymorphisms do not enable to distinguish between two types of mixed sport disciplines thus suggesting that for a higher resolution distinction other genetic markers may be needed. Indeed, the PPAR $\alpha$ GG genotype is more prevalent in soccer players which result, 
among the mixed exercise phenotypes, the most endurance-oriented athletes. In this regard, it was interesting to note that $5 \%$ of the soccer players exhibited the highest TGS (87.5) for endurance with another $22 \%$ of the cohort showing a TGS of $\sim 75$. Accordingly, there is evidence that the majority of total energy consumption of a soccer-related performance is from aerobic metabolism. This finding clearly indicates that maximal aerobic power is very likely the most important component for success in soccer (38).

\section{CONCLUSION}

The present study provides support for an association between PPAR $\alpha$ polymorphism and athletic status in Italian male soccer players. The findings indicate that the PPAR $\alpha$ polymorphism may be suitable as distinguish genetic marker among mixed sport disciplines.

Further studies examining the athletes' competitive level and adding more information about physical, technical and tactical characteristics of them might confirm our preliminary remarks.

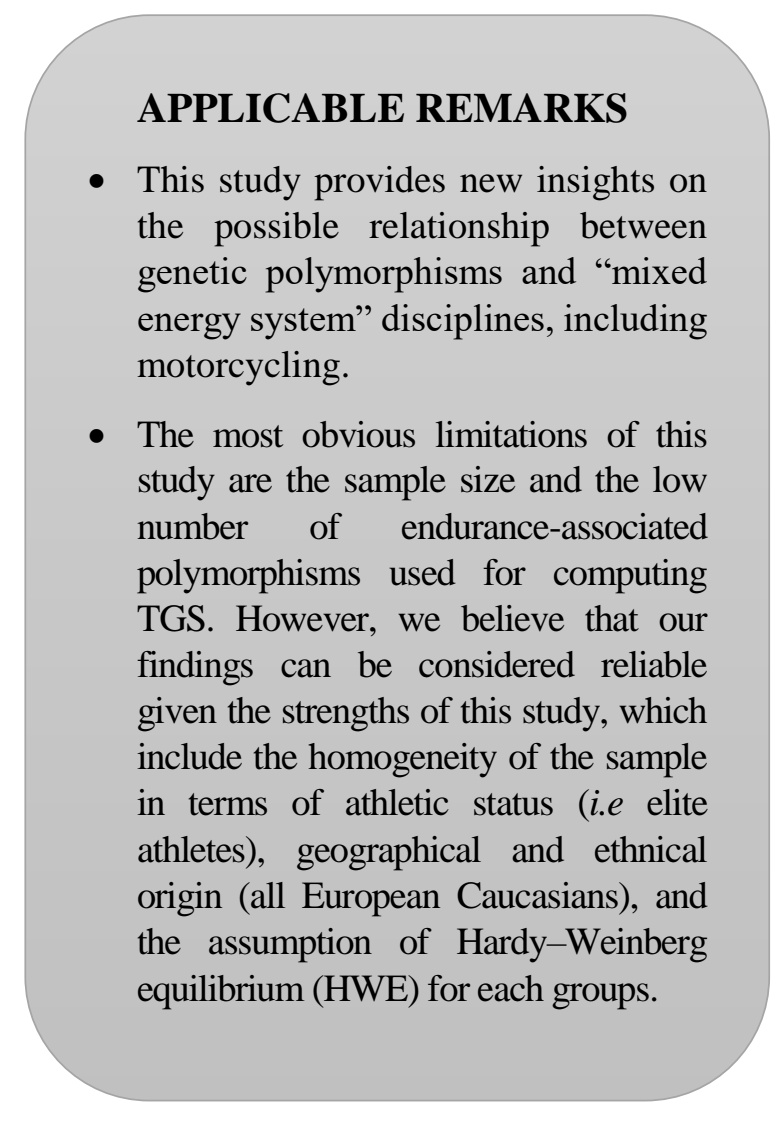

\section{REFERENCES}

1. Milioni F, Zagatto AM, Barbieri RA, Andrade VL, Dos Santos JW, Gobatto CA, da Silva AS, Santiago PR, Papoti M. Energy Systems Contribution in the Running-based Anaerobic Sprint Test. International journal of sports medicine 2017; 38: 226-32. [DOI:10.1055/s-0042-117722] [PMID]

2. Spencer MR, Gastin PB. Energy system contribution during 200- to 1500-m running in highly trained athletes. Medicine and Science in Sports and Exercise 2001; 33(1):157-62. [DOI:10.1097/00005768-200101000-00024] [PMID]

3. Dellal A, Varliette C, Owen A, Chirico E, Pialoux V. Small-sided games versus interval training in amateur soccer players: Effects on the aerobic capacity and the ability to perform intermittent exercises with changes of direction. Journal of Strength and Conditioning Research 2012; 26, 2712-720. [DOI:10.1519/JSC.0b013e31824294c4] [PMID]

4. Gobbi AW, Francisco RA, Tuy B, Kvitne RS. Physiological characteristics of top level off-road motorcyclists. British journal of sports medicine 2005; 39: 927-31; discussion 31. [DOI:10.1136/bjsm.2005.018291] [PMID] [PMCID]

5. Di Giminiani R, Visca C. Explosive strength and endurance adaptations in young elite soccer players during two soccer seasons. PLoS ONE 2017; 12(2), e0171734. [DOI:10.1371/journal.pone.0171734] [PMID] [PMCID]

6. Ho LA. Explosive Power and Anaerobic Endurance for Wrestlers. In 31 International Conference on Biomechanics in Sports 2013. https://ojs.ub.uni-konstanz.de/cpa/article/viewFile/5521/5015.

7. Eynon N, Ruiz JR, Oliveira J, Duarte JA, Birk R, Lucia A. Genes and elite athletes: a roadmap for future research. The Journal of Physiology 2011; 589(Pt 13):3063-3070. [DOI:10.1113/jphysiol.2011.207035] [PMID] [PMCID]

8. Maffulli N, Margiotti K, Longo UG, Loppini M, Fazio VM, Denaro V. The genetics of sports injuries and athletic perfance. Muscles, ligaments and tendons journal 2013; 3: 173-89. [PMID] [PMCID]

9. Ahmetov I, Egorova ES, Mustafina LJ. The PPARA gene polymorphism in team sports athletes. Central European Journal of Sport Sciences and Medicine 2013; vol. 1, pp. 19-24.

10. Batavani MR, Marandi SM, Ghaedi K, Esfarjani F. Comparison of muscle-specific creatine kinase (CK-MM) gene polymorphism (rs8111989) among professional, amateur athletes and non-athlete karatekas. Asian Journal of Sports Medicine 2017; 8(2):e43210. [DOI:10.5812/asjsm.43210] 
11. Ehlert T, Simon P, Moser DA. Epigenetics in sports. Sports medicine 2013; 43: 93-110. [DOI:10.1007/s40279012-0012-y] [PMID]

12. Lucia A, Moran M, Zihong H, Ruiz JR. Elite athletes: are the genes the champions? International journal of sports physiology and performance 2010; 5: 98-102. [DOI:10.1123/ijspp.5.1.93] [PMID]

13. Ulucan K, Biyik B, Kapici S, Sercan C, Yilmaz O, Catal T, Alpha-Actinin-3 R577x Polymorphism Profile of Turkish Professional Hip-Hop and Latin Dancers. Annals of Applied Sport Science 2016; 4(4): 1-6. [DOI:10.18869/acadpub.aassjournal.4.4.1]

14. Arslan KA, Akpunar F, Sercan C, Kapıcı S, Ulucan K. Slc2a4 Polymorphisms Can Be A New Molecular Biomarker for Sports Genomics. Annals of Applied Sport Science 2017; 5(3): 1-3. [DOI:10.29252/acadpub.aassjournal.5.3.1]

15. Eynon N, Meckel Y, Sagiv M, Yamin C, Amir R, Sagiv M, Goldhammer E, Duarte JA, Oliveira J. Do PPARGC1A and PPARalpha polymorphisms influence sprint or endurance phenotypes? Scandinavian journal of medicine \& science in sports 2010; 20: e145-50. [DOI:10.1111/j.1600-0838.2009.00930.x] [PMID]

16. Fedotovskaia ON, Popov DV, Vinogradova OL, Akhmetov, II. [Association of the muscle-specific creatine kinase (CKMM) gene polymorphism with physical performance of athletes]. Fiziologiia cheloveka 2012; 38: 105-9. [DOI:10.1134/S0362119712010082]

17. Pimenta EM, Coelho DB, Veneroso CE, Barros Coelho EJ, Cruz IR, Morandi RF, De APG, Carvalho MR, Garcia ES, De Paz Fernandez JA. Effect of ACTN3 gene on strength and endurance in soccer players. Journal of strength and conditioning research 2013; 27: 3286-92. [DOI:10.1519/JSC.0b013e3182915e66] [PMID]

18. Sessa F, Chetta M, Petito A, Franzetti M, Bafunno V, Pisanelli D, Sarno M, Iuso S, Margaglione M. Gene polymorphisms and sport attitude in Italian athletes. Genetic testing and molecular biomarkers 2011; 15: 285-90. [DOI:10.1089/gtmb.2010.0179] [PMID]

19. Akhmetov, II, Popov DV, Mozhaiskaia IA, Missina SS, Astratenkova IV, Vinogradova OL, Rogozkin VA. [Association of regulatory genes polymorphisms with aerobic and anaerobic performance of athletes]. Rossiiskii fiziologicheskii zhurnal imeni IM Sechenova 2007; 93: 837-43. [PMID]

20. Ginevičienė V, Pranckevičienė E, Milašius K, Kučinskas V. Relating fitness phenotypes to genotypes in Lithuanian elite athletes. Acta Med Litu 2010; 17(1-2):1-10. [DOI:10.2478/v10140-010-0001-0]

21. Varley I, Hughes DC, Greeves JP, Stellingwerff T, Ranson C, Fraser WD, Sale C. The association of novel polymorphisms with stress fracture injury in Elite Athletes: Further insights from the SFEA cohort. Journal of science and medicine in sport 2017.

22. Saab YB, Kabbara W, Chbib C, Gard PR. Buccal cell DNA extraction: yield, purity, and cost: a comparison of two methods. Genetic testing 2007; 11: 413-6. [DOI:10.1089/gte.2007.0044] [PMID]

23. Abbas S, Raza ST, Chandra A, Rizvi S, Ahmed F, Eba A, Mahdi F. Association of ACE, FABP2 and GST genes polymorphism with essential hypertension risk among a North Indian population. Annals of human biology 2015; 42: 461-9. [DOI:10.3109/03014460.2014.968206] [PMID]

24. Schadock I, Schneider A, Silva ED, Buchweitz MR, Correa MN, Pesquero JB, Paredes-Gamero EJ, Araujo RC, Barros CC. Simple Method to Genotype the ACTN3 r577x Polymorphism. Genetic testing and molecular biomarkers 2015; 19: 253-7. [DOI:10.1089/gtmb.2014.0299] [PMID]

25. Proia P, Bianco A, Schiera G, Saladino P, Contro V, Caramazza G, Traina M, Grimaldi KA, Palma A, Paoli A. PPARalpha gene variants as predicted performance-enhancing polymorphisms in professional Italian soccer players. Open access journal of sports medicine 2014; 5: 273-8. [PMID] [PMCID]

26. Ruiz JR, Gomez-Gallego F, Santiago C, Gonzalez-Freire M, Verde Z, Foster C, Lucia A. Is there an optimum endurance polygenic profile? The Journal of physiology 2009; 587: 1527-34. [DOI:10.1113/jphysiol.2008.166645] [PMID] [PMCID]

27. Lopez-Leon S, Tuvblad C, Forero DA. Sports genetics: the PPARA gene and athletes' high ability in endurance sports. A systematic review and meta-analysis. Biology of Sport 2016; 33(1): 3-6. [PMID]

28. Maciejewska A, Sawczuk M, Cieszczyk P. Variation in the PPARalpha gene in Polish rowers. Journal of science and medicine in sport 2011; 14: 58-64. [DOI:10.1016/j.jsams.2010.05.006] [PMID]

29. Schmitt B, Fluck M, Decombaz J, Kreis R, Boesch C, Wittwer M, Graber F, Vogt M, Howald H, Hoppeler H. Transcriptional adaptations of lipid metabolism in tibialis anterior muscle of endurance-trained athletes. Physiological genomics 2003; 15: 148-57. [DOI:10.1152/physiolgenomics.00089.2003] [PMID]

30. Russell AP, Feilchenfeldt J, Schreiber S, Praz M, Crettenand A, Gobelet C, Meier CA, Bell DR, Kralli A, Giacobino JP, Deriaz O. Endurance training in humans leads to fiber type-specific increases in levels of peroxisome proliferator-activated receptor-gamma coactivator-1 and peroxisome proliferator-activated receptor-alpha in skeletal muscle. Diabetes 2003; 52: 2874-81. [DOI:10.2337/diabetes.52.12.2874] [PMID]

31. Tural E, Kara N, Agaoglu SA, Elbistan M, Tasmektepligil MY, Imamoglu O. PPAR-alpha and PPARGC1A gene variants have strong effects on aerobic performance of Turkish elite endurance athletes. Molecular biology reports 2014; 41: 5799-804. [DOI:10.1007/s11033-014-3453-6] [PMID] 
32. Fedotovskaya O, Eider J, Cięszczyk P, Ahmetov I, Moska W, Sawczyn S, Ficek K, Leońska-Duniec A, Maciejewska-Karłowska A, Sawczuk M, Czubek Z, Żychowska M, Jascaniene N. Association of muscle-specific creatine kinase (CKM) gene polymorphism with combat athlete status in Polish and Russian cohorts. Archives of Budo 2013; ICID: 889021.

33. Massidda M, Corrias L, Scorcu M, Vona G, Calò MC. ACTN-3 and ACE genotypes in elite male Italian athletes. Anthropological review 2012; Vol. 75 (1), 51-59. [DOI:10.2478/v10044-012-0004-4]

34. Scott RA, Irving R, Irwin L, Morrison E, Charlton V, Austin K, Tladi D, Deason M, Headley SA, Kolkhorst FW, Yang N, North K, Pitsiladis YP. ACTN3 and ACE genotypes in elite Jamaican and US sprinters. Medicine and science in sports and exercise 2010; 42: 107-12. [DOI:10.1249/MSS.0b013e3181ae2bc0] [PMID]

35. Kikuchi N, Ueda D, Min SK, Nakazato K, Igawa I. The ACTN3 XX Genotype's Underrepresentation in Japanese Elite Wrestlers. International journal of sports physiology and performance 2013; 8, 57-61. [DOI:10.1123/ijspp.8.1.57] [PMID]

36. Orysiak J, Busko K, Michalski R, Mazur-Rozycka J, Gajewski J, Malczewska-Lenczowska J, Sitkowski D, Pokrywka A. Relationship between ACTN3 R577X polymorphism and maximal power output in elite Polish athletes. Medicina 2014; 50: 303-8. [DOI:10.1016/j.medici.2014.10.002] [PMID]

37. Eynon N, Ruiz JR, Femia P, Pushkarev VP, Cieszczyk P, Maciejewska-Karlowska A, Sawczuk M, Dyatlov DA, Lekontsev EV, Kulikov LM, Birk R, Bishop DJ, Lucia A. The ACTN3 R577X polymorphism across three groups of elite male European athletes. PloS one 2012; 7: e43132. [DOI:10.1371/journal.pone.0043132] [PMID] [PMCID]

38. Castagna C, Abt G, D'Ottavio S. Physiological aspects of soccer refereeing performance and training. Sports medicine 2007; 37: 625-46. [DOI:10.2165/00007256-200737070-00006] [PMID] 